\title{
Shamanism Influence in Inuit Art-Dorset Period
}

\author{
Bogliolo Bruna Giulia \\ Centre d’Etudes Arctiques, Paris, France; Centro Studi Americanistici “Circolo Amerindiano” Perugia, Italy
}

\begin{abstract}
Native Inuit developed a complex system of shamanic-oriented thinking. They filled the frozen immensities of the Arctic with a number of omnipresent ghosts and spirits. In its shamanic-religious dimension, the Dorset art (circa 1000 B.C. to circa 1000 A.D.), stemming from a culture moulded by shamanic practices and burial rites, kept memory of the Times of Origins, shaped a very rich symbolic universe, suggested, and outsourced the secret correspondences between the micro and macro cosmos. The present paper investigates the thigh correspondence and relationship between the Inuit-Dorset shamanic view of the world and their miniaturized art.
\end{abstract}

Keywords: Arctic, Inuit, Dorset, Sananguaq, shamanism, art

\section{Introduction}

The paper investigates the Dorset-period Inuit art, crossing ethnohistory, anthropology, and sociology of religion. The native Inuit art, at the time techne, mimesis, and objectivation of a magic real, is inspired with a "useful beauty", which does not dissociate the estetich pleasure from the functional efficiency. The miniaturisation of native Inuit objects allows their transportation by these nomad hunters. The objects serve as a chamanic support to complex rituals of transformation founded on the correspondences linking the microcosm to the macrocosm. As the polyvalent transposition of a cosmovision, of shared values, and of knowledge into carved objects, the artistic language of Dorset turns out a chamanic thinking which is founded on the assuption of the connaturallity of realms and the matamorfism.

\section{A Shamanic View of the World}

Native Inuit developed a complex system of shamanic-oriented thinking. They adopted an original perception of the space-time ${ }^{1}$ and they felt themselves an "instant of eternity", an infinitesimal part of a pulsing universe undergoing a continuous metamorphosis.

Within their immanent pantheism, these men imbedded in the sacred privileged an empathetic apprehension of the cosmos: Through a sensitive and intuitive approach, they were willing to decrypt the occult language of a Nature governed by a hidden order to be enforced.

In syntony with a conception of a living and organic cosmos, they trusted the transmigration and reincarnation of souls: "[...] life is eternal. But nobody knows under which form he is to be born again" told Kivkarjuk to the ethnologist Knud Rasmussen (Rasmussen, 1994, p. 104).

\footnotetext{
Bogliolo Bruna Giulia, doctor, Centre d'Etudes Arctiques, Paris; Centro Studi Americanistici “Circolo Amerindiano” Perugia. ${ }^{1}$ For an extensive analysis on the Inuit shamanism and its embeddedness in anarcho-communalist morphology of Inuit traditional communities, we refer to Bruna's (2012) Chapter 3 and chapter 6.
} 
Under the mark of ambivalence and metamorphosis, native Inuit filled the frozen immensities of the Arctic with a number of omnipresent ghosts and spirits-both protecting and hostile, originating from the heavens and the hell, supporting and pathogen, who surrounded, protected and/or harassed these "nomads of the cold deserts", who feared, as claimed by the shaman Aua:

[...] the dead men as well as the souls of killed animals [...], the spirits of the land and the air... whatever is unknown... whatever surrounds us... and whatever we know through the stories and the myths. That is why we have got our practices. That is why we are to respect our taboos. (Rasmussen, 1994, pp. 182-183)

Despite the absence of a right codified under a written form, the empire of the norm governed the native Inuit society. It was passed through oral tradition, sublimated in the mythology and consecrated by the shamanic rituals. The contravention of the atavistic rules, which enabled the cosmos "to 'stand' and not to crash destroying the men” (Malaurie, 2003a, pp. 109-110), caused disorder and engendered the risk, so dreaded by the Inuit people, to come back to the primeval chaos. The rejection of any formal hybridism, such as the hanging status of the "in-between"-expression of a non-achieved process rich of ambivalent potentialities, which could have produced the deregulation of the ecological system and eventually the anomy-originated from that fear.

Thus, infringing ancestral taboos — which obeyed a complex logic_—and breaking the weak environmental equilibrium were interpreted as insane and fateful acts of hybris. They were felt as socially dangerous, because they were able to trigger a deregulation engendering dreadful natural catastrophes, starvation, famines, and extended suffering, which were to affect the whole group, because within a communalist society the responsibility of individual faults was to be assumed by the whole community.

The angakkoq — the shaman — only was allowed to restoring the infringed harmony. The shaman was able to connect the worlds of the dead and alive:

He can open the doors of the dreams, he heartens to the trance and to the overcoming, he can connect the visible to the invisible, the animal to the human worlds; he is common breathing, pulsation, hypnosis. (Geoffroy-Schneiter, 2006, pp. 325-326)

As a powerful intercessor among the world of humans and the forces of the Nature, the dead and the alive, the game and the hunters, a medium and a healer, this marginal person, often different by his sexual orientation, showed the apparent attributes which established his charisma and legitimized his social status.

Spiritual guide of the whole community and medicine-man, the angakkoq spoke the taartaq, the exoteric and sacred language of the spirits (and mainly the auxiliary ones, the toornat, and the personal ones, the toornaarsuk), with whom he was able to communicate. This language, punctuated with archaic, old-fashioned, and mysterious words and terms, ${ }^{2}$ was fully unintelligible to laymen.

Undergoing an initiatory route punctuated with very hard ordeals, including the experience of a symbolic death-resurrection process, the novice shaman acquired a subtle intelligence of the matter, a penetrating vision of things (Bogliolo Bruna, 2007). The wisdom opened and cleared the angakkoq the way to a sort of interior view.

Through a process of carnal dispossession and detachment from the perceptible world, the shaman

\footnotetext{
${ }^{2}$ According to Talbitzer's the "language of the spirits is made with archaic words which are reserved to the priests. I established a friendly relationship with Mitsuarnianga, an angakkoq, who had been baptised [...], he taught me a thousand words of the sacred language" (Thalbitzer, 1930, p. 75).
} 
succeeded to drop out his formal dressing as well as his perishable envelope of flesh and blood. During his ecstatic trance, he transformed and travelled, as a spirit, throughout the worlds of the cosmos, under the sea to the formidable and feared Sedna, the mistress of the marine animals, in the sky, among the stars, to the Moon-man, to quell his anger. Because peacekeeping was token of fertility, condition sine qua non of survival.

As a magician, who through invocations, songs, and talismans, succeeded apprising the inhabitants of the hidden worlds, this sighted-man, this "traveller of the invisible" penetrated the mysteries of the living, not through breaking, but by affinity and empathy. That way, he acquired an immediate consciousness of hidden realities and touched upon the mysteria mundi.

Freed from the ascendency of the self, the angakkoq, tuned to the universal sap, penetrated, by osmosis, the secret intelligence of the cosmos, became a collective agent of reconciliation, established the primacy of the social rule and restored the harmony of the ecosystem which the carelessness, or the shamelessness of some individuals could have jeopardized.

\section{When the Shamanic Thinking Materializes into Object}

Epiphany of a shamanic thinking, the Inuit art "sananguaq"3 was the tangible and positive transcription of a global vision of the cosmos.

As a transmitter of founding myths and a very rich imaginary, the language of Dorset carving was the enchanting reifying of a shamanic thinking. Shaped by the aesthetics of the "useful beauty", which privileges functionality, it relied upon the emergency principle.

The hand cherished the matter and tried to reveal the image which was hidden inside, the "latent topic" which it accommodated: "The spirit belonging to the matter, claims Jean Malaurie, the form fitted the hard core of the bone or the stone, establishing a dialogue with the dead" (Malaurie, 1999, p. 360).

In its shamanic dimension, the Dorset art (circa 1000 B.C. to circa 1000 A.D.), stemming from a culture moulded by shamanic practices and burial rites, kept memory of the Times of Origins, shaped a very rich symbolic universe, suggested, and outsourced the secret correspondences between the micro and macro cosmos.

Tightly nested with the geography of the land, the hunter opened up to a "mystic participation": In that way, carving became an eminently religious act because the native Inuit were mainly Homines Religiosi, thirsting for sacred.

Sensitive to the voice of a matter, which was felt as a living one, were it ivory, antler, wood, or stone, the artistic expression of Inuit was featured by the stylistic originality, the meticulousness of the handling (despite the very rudimentary stone-equipment), the euphoric complexity of the forms, and the longevity of its typology.

According to Blodgett's assumption, some hunters especially cared the carving of these magic works, endowed of power, and featured with a real refinement and a noticeable workmanship: "Maybe it was a shaman's role" (Blodgett, 2001, p. 97).

Such a fascinating beauty of an art embedded in the sacred, which strived to make visible the invisible,

\footnotetext{
3 The etymology of the word sananguaq — "sana" addressed "the action of doing” and "nguaq" "the imitation and/or the scaled copy of the reality"- - summarizes the two aspects of the mind-process which conduct and govern the Inuit hunter-artist's act of creation. In its inner polyvalent nature of plastic translation of a shamanic thinking, of transmission agent of founding myths, and of surviving memory of ancestral acts, the native Inuit art does not split esthetical enchantment and efficiency, "doing well” and "being able to do".
} 
adopting a large set of stylistic canons: naturalistic, symbolic, figurative, and surrealist ones, essential and baroque as well.

No "esthetical gratuitousness" was allowed in this original and inventive language, which nested, with grace, beauty, and utilitarian pragmatism.

\section{Within the Infinitesimal, the Totality of the World: The "Power" of a "Useful Beauty"}

The native Inuit's "oneiric seeing" built the image of a world where natural and supernatural were tightly nested and overlapped: The miniatures were the tangible manifestation of this image.

As nomads, the Inuit carved small anthropomorphic, zoomorphic, and hybrid figures, which were voluntarily miniaturized to easy their transportability.

Far from seeking for an abstract beauty, these animist hunters adopted with both dexterity and virtuosity, an audacious and cryptic carving mode, which embedded in the matter an extremely rich symbolic universe and a roving imaginary. ${ }^{4}$

The choice of materials was not banal: A tight correlation held between the brute and row materials and the final artefacts:

The symbolic relationship among the antler, the land, the summer and the man opposes to the one which links the ivory, the sea, the winter and the woman; thus, the hunters hunt the land-mammals during the summertime with antler-pointed weapons and the sea-animals in the wintertime with ivory-pointed harpoons. (Blodgett, 2001, p. 99)

Worrying the wondering souls of the dead and the killed game, the ancestors and the malevolent spirits, who spied upon them and bewitched their nightmares, the Inuit lived embeddedly in an ambivalent "dreamy Nature", fascinans and terrifying, at the time. They were to strictly obey the prescriptions and the taboos of hunting, which turned out a very stringently codified and ritualized activity. Any transgression was to stimulate the hostility of the invisible spirits and to stop the availability of the game. To appease their fear and protect them, the angakkoq carved their ivory and bone amulets.

The profane watches in admiration these small, extremely well-shaped, Lilliputian handicrafts: They speak the dumb, ambiguous tongue of an art which is not intended to be such an art which challenges the tricky appearances. To address them, he is to free himself from a preformed form of seeing which secularizes the reality to meander in the plastic labyrinth of the "treacherous appearances".

As the watchable metamorphosis of a magic thinking, and also the miniaturized copies of a magic, at the time visible and invisible, these handicrafts ${ }^{5}$ are, from many viewpoints, the emblematic transcription of a shamanic vision of the reality, which postulates and assumes the ontological connaturally of realms.

Within an organic system of the Nature, the infinitesimal and the extremely big face to each others, enjoy the same substance and share a common finality. The change of scale demonstrates and claims the native Inuit's

\footnotetext{
${ }^{4}$ It is quite hard carving materials at a very small scale, mainly the wood: The carver-artist possesses an extraordinary dexterity, an ability inherited by survival and lasting for generations.

${ }_{5}$ Beluga whale, Igloolik area, Middle Dorset culture, Hull Canadian Museum of Civilisations, ivory (Retrieved from http://www.historymuseum.ca/cmc/exhibitions/archeo/paleoesq/images/pega3-4b.jpg).

Weasel, Igloolik area, Late Dorset culture, Hull Canadian Museum of Civilisations, ivory. (Retrieved from http://www.historymuseum.ca/cmc/exhibitions/archeo/paleoesq/images/pega4-5b.jpg).

Seal, Bathurst Island, Late Dorset culture, Hull Canadian Museum of Civilisations, ivory (Retrieved from http://www.historymuseum.ca/cmc/exhibitions/archeo/paleoesq/images/pega1-3b.jpg).
} 
unitary vision of the cosmos; the very small and the very big were allowed to flirt in such a magic, evolving and diverse universe.

In the framework of an economy or rarity (caused by the lack of resources) which featured the Inuit's everyday life, a utilitarian pragmatism was very necessary: No Inuit's artefact was missing an immediate functionality. Thus, each magic object possessed a transforming power: from an inanimate being to a living one, from a death agent to a source of life. The founding concept of metamorphosis-amplification was present in the myths, mainly the ethno-genesis ones.

These miniaturized many-meaning artefacts, which can be held in a hand, complied with an aesthetic and shamanic vision of the world, which emphasized the alchemic alliance of the beautiful and the useful, the realistic and the symbolic. The mimetic reproduction of the arctic game conformed to that of zoomorphic and zoo-anthropomorphic hybrid creatures (bear-headed hawks, wolf-woman) and the symbolism of the quasi-abstract small figures, which stand for the hunt-supporting spirits.

Such a powerful creative capacity of these nomad-hunters may be the shamans who specialized in this naturalist, stylized and visionary at the time, animal-art, which was the expression of a "religious ecology"!

The ravished observer watches "as an aesthete" these thaumaturgical and propitiatory amulets, small wonders of grace made of ice with outstanding ability; ageless handicrafts with a strong expression endowed with power, which represent the shaman's own auxiliary spirits and mainly, the bear-spirits and the sublime and mysterious "small masks" which sometimes recall the Time of Origins. A hypnotic strength emanates from the small mask found in the Tyara site, ${ }^{6}$ a shamanic mysterious icon, of an ambiguous and ageless beauty. Confined in its eternal, hieratic silence, this miniature impregnated with sacred draws the sight: May it be a mask-spirit, a miniaturized funerary mask, or a worrisome index of an unaccomplished metamorphosis? Indeed, a hint of animal nature seems to last in this enigmatic face which captures and questions the observer. Two very tiny, just sketched, wolf-ears stick-out the concave front; two grooves encircle the nose, as if they were expression wrinkles.

Such an astonishing carving of apparent realism serves a magic thinking which materializes in the handicrafts; "watching and watching again the native masks to see them, as people listen to the music to try to grasp it: among the notes” (Malaurie, 2001, p.12).

Reiterated transformations, "metamorphosis of souls" within a unified system where any ontological breaking among realms is denied: It is worth setting these mysterious objects in the framework of animistic vision.

The native Inuit, animist hunters who enjoyed a tremendous observation capacity, carved with an outstanding skill, animal-shaped miniatures, scaled wood and ivory copies of the arctic game: young bears, small seals, birds of different species, walruses, and musk-oxen. Moreover, they were able to catch, within an instant-glimpse, the immediacy of the animal behaviour. Birds were represented with their wings a little unfolded as if they were to fly away or to prepare attacking. The wild bears watched the prey.

\footnotetext{
${ }^{6}$ Tyara masque, ivory, $35 \times 35$ × $20 \mathrm{~mm}, 8 \mathrm{~mm}$ deep, previously identified-in the catalogue of Canadian Museum of Civilisations (Now Canadian Museum of History) — as an Ancient Dorset artefact, originating from a debris layer located in the Tyara site, Sugluk Island, Hudson Strait, dating from 720 B.C., is now indicated in the same catalogue as a belonging to the $\begin{array}{lllll}\text { Classical Dorset } & \text { period } & \text { (1-500 } & \text { A.D.) } & \text { (Retrieved }\end{array}$ http://www.museedelhistoire.ca/cmc/exhibitions/archeo/paleoesq/images/peint04b.jpg).
} 
Major attention was devoted to the bears, which were caught in euphoric panoply of postures: standing, swimming, flying, sitting such as dogs and walking heavy and majestic steps.

All anatomic details were represented with an impressive realism, even if the images of the boreal game always possessed a symbolic meaning. Among the indicators of the shamanic influence, it is worth mentioning the visible depiction of the animal spine and ribs in the back.

Mirror-animal of human beings, the bear, nanook, embodied the chthonian and land deities, participated in the initiation of the trainee young shaman, who was to face more and more difficult passage ordeals, up to losing his carnal integrity:

He loses his blood, his skin: His limbs undergo dislocation, his bones break off the body in turn. He watches his bones at his feet spread off on the land. His young power-whether he has been able to acquire it-enables him to recover getting bear features. He then communicates with the animal yelling. (Malaurie, 2003b, pp.18-19)

Through an exteriorisation process, the shaman-to-be freed from crystallized forms. After defeating the appearances—-which alone freeze and fashion the being - he recovered under bear features. Then, he was at the time other vs himself; and more himself then before, because the extreme mystic and ecstatic experience he just went through had been at the time an anamnesis of the long and difficult process to become a man and a mean to access the true knowledge.

Nevertheless, whether he was not willing to sink into the madness, he was to come back to his original human features:

He is to wake-up bare, but conscious that a shamanic wisdom has been granted to him. He is to know that-from now on - he can be double, inhabited by his tartoq, which enables him to dialogue with the spirits and, if needed, fight against them, too. (Malaurie, 2003b, p. 19)

Merging in the cosmos involved for the young shaman a double process of wavering from his identity and overcoming the every-day reason, which confined his mind in a carnal envelope. This process of carnal dispossession and sensorial distancing allowed him to catch the Nature’s mind.

\section{The Shaman-Bear}

The native Inuit carving addressed these troubling metamorphoses and mainly the transitional status of the angakkoq, in between life and death, during his strange mutation to nanook-bear, and vice-versa.

Among the anatomic features which remainder the shamanism, we mention the visible details of the skeleton $^{7}$ and the animal dentures ${ }^{8}$ — with very long uncovered jaws, such as either wolf or bear ones—which provide with "an impressive feeling on the way a human face can turn in animal snout" (McGhee \& Sutherlant, 2008, p. 45).

\footnotetext{
${ }^{7}$ Floating or flying bear, Igloolik area, Middle Dorset culture, Hull Canadian Museum of Civilisations, ivory (Retrieved from http://www.museedelhistoire.ca/cmc/exhibitions/archeo/paleoesq/images/pegb3-1b.jpg).

8 Carved in ivory, these dentures are well fitted to human teeth-set. As the visible marks of teeth allow guessing, these dentures could have been used by the angakkoq during the shamanic rituals, i.e., Shaman's teeth, Igloolik area, Early Dorset culture, Hull Canadian Museum of Civilisations, (Retrieved ivory from http://www.museedelhistoire.ca/cmc/exhibitions/archeo/paleoesq/images/pegm2-6b.jpg).
} 
Moon and night animal ${ }^{9}$ having a massive body, the bear was the above-all mediator among the man, the supernatural and the primeval might of the Nature.

Enjoying a strange and captivating beauty, nanook-the angakkoq took the features of which during a trance, when he communicated with the spirits—-was carved in compliance with a stylistic register which gathered the realism (an outstanding precision of anatomical features and details) and the symbolism (representation of hybrid creatures, such as the bear-headed hawk, charging of symbolic meaning and evocating the shaman's metamorphoses). The surface of the body was covered with horizontal and vertical lines: The vertebrae and the ribs were clearly apparent, the cross-points of articulations, where the soul was able to enter and get off the body, were marked with $\mathrm{a}+$ and $\mathrm{a} \times$ was carved on the top of the skull. The bears very likely were ritual objects, as it can be suggested by the presence of small spots of red ochre, which were also found on the ceremonial masks.

Accordingly, the small statues of floating bears, which have been found in the excavation of several East-Arctic Dorset villages, enable guessing the existence of some homogeneity in the artistic canons.

Any comprehensive and "friendly" approach of the Dorset Inuit art cannot avoid considering the intrinsic polysemy of these multi-functional miniatures which were the figurative transposition of a transforming and acting shamanic thinking.

Outward sign of a widespread supernatural (malevolent and benevolent spirits, roaming souls of the dead were never faraway) and manifestation of dreamlike visions and obsessions, which grieved these animist hunters, the carving language, inhabited by the breath of the sacred, juggled with naturalism and surrealism because the hunter-carver, who behaved as a shaman, enjoyed the vision of the being and its appearance at the time.

Charged with symbolism, the miniatures_-"small thinking”-which urge to meditate, "silent prayers" embedded in a living and animated matter claim the connaturality among the realms and translate a unitary vision and the vitalism of the universe where microcosm and macrocosm face to each other and dialogue. In that way, the hyperrealism enriches with symbolic meaning.

The polysemic language of the delightful small animal figures commands an interpretation code which overcomes the mere appearances to address the hidden meaning of Dorset art.

How can one be insensitive to the enigmatic beauty of these stylized faces, carved in the bone and the ivory, which feature the surface of ceremonial objects with human countenance?

\section{The Mixed Time of Reencounter}

A shamanic tube (Canadian Museum of Civilisations) — marvellous ivory three-dimensional work, which combines in balanced equilibrium animal images (seals, walrus) and human features—has very likely been used during therapeutic rituals. No doubt it is a powerful shamanic handicraft. The subdivision of the space on the surface evocates the frontier-quite porous, indeed—existing between the human and animal realms. A seal is located on the very top of the tube, stretched-out as if it were lying-down on the ice-pack. It is surrounded by two walrus heads, the tusks of which join above the seal, drawing a loop. In the lowermost part of the handicraft, a human face with very large nostrils, which look like the nose pockets of seals, is carved. Is the morphological detail to remember per metonymy either the hard and long process in humanisation of the Inuit people or the

\footnotetext{
${ }^{9}$ Chevalier \& Gheerbrant, 1966, p. 717: “In Siberia and Alaska [the bear] is related to the Moon, because it disappears in winter and comes back in springtime".
} 
Time of Origins when the humans and the animals were able to exchange, communicate, and change their features in turn? Could it be a sign of a metamorphosis under the way? Moreover, do the hollowed eye cavities remember the visionary power of the angakkoq?

Anyway, such as an unresolved rebus, this power-holding object, connected to magic and/or religious practices, keeps its secret.

Such a hallucinatory baroque in these antler ceremonial sticks (late Dorset culture), the surface of which is swarming and teeming with human faces, with polymorphic features, terrifying and grotesque at the time, sneering and greening or hieratic, fearful, dreadful, and misshaped as they were in a deep suffering. An animal ascendency is suggested by the dilation of the nostrils. The mouths are twisting about in pain, the thick lips round to breathe or to hiss, as if these supernatural beings, dead or alive, strived to be in touch with the world of humans. It is worth remembering that native Inuit believed that benevolent ghosts revealed themselves through whistling. The shaman-carver was willing to make visible the invisible.

Such a hallucinatory baroque of ghost images, which rise from the unknown and the unconscious of distressed people; they were the plastic metaphor of the dumb dialogue among the living and the dead! Such twisting whirl of hierophantic figures, of auxiliary or malevolent spirits, of mortal and supernatural beings, fill and colonize the space which serves as an intermediary between the immanent and the supernatural worlds!

"They may have been the anthropomorphic gods of a palaeo-Eskimo pantheon” (McGhee, 1989, p. 63), or they may have been a community of dead and alive or even the auxiliary spirits of the shaman who possessed and used these objects.

Repository of hidden and acting powers, and also memory-objects, these shamanic sticks also remember the first encounters with Europeans, as shows the face of a white man carved at the very bottom of an antler stick. Is he a stranger, an allaq, who is such because he does not belong to the group and the land? Can we guess that this depicted Qallunaat (the White), very likely a Viking dweller, joined and was integrated in the pantheon of the auxiliary spirits?

\section{Conclusion}

To access the polyvalence of the Dorset Inuit plastic universe, the "thinking eye" has to free from a seeing which secularizes and rationalizes the reality: It must learn to jungle with the "treacherous appearances" and the secret dictionary of signs.

No "aesthetic gratuity" in this masked and out-timed carving language-which is presence, metaphor, and mimesis, is of a magic real, as well.

"Convulsive" and fascinating beauty of this art is not intended to be like this, in its sparkling varietas of stylistic canons, naturalistic, symbolic, realistic, and surrealistic at the time.

In the infinitesimal, the world in a whole!

\section{References}

Barou, J. P. (2002). L'œil pense. Essai sur les arts primitifs contemporains (The thinking-eye. Essay on contemporary native art). Paris: Payot.

Berlo, J., \& Philips, R. (2006). Native north American art. Oxford: Oxford University Press.

Birket-Smith, K. (1945). Ethnographical collections from the northwest passage (Report of the fifth Thule expedition, 1921-1924). 
Copenhagen: Gyldendal.

Birket-Smith, K. (1955). Mœurs et coutumes des Esquimaux (Eskimos’ Usages and Practices). Payot: Paris.

Blodgett, J. (1979). The coming and going of the shaman: Eskimo Shamanism and art. Winnipeg: Winnipeg Art Gallery.

Blodgett, J. (2001). L'art des Inuit du Canada. In J. Malaurie (Dir.), L'art du grand Nord (The Inuit art in Canada. In J. Malaurie (Dir.), Far-North art) (pp. 95-158). Paris: Citadelles \& Mazenod.

Boas, F. (1888). The central Eskimo, 6th annual report of the bureau of ethnology to the secretary of the Smithsonian Institution. Washington and Lincoln: Smithsonian Institution-Bureau of Ethnology and University of Nebraska.

Bogliolo Bruna, G. (1992). Les premiers regards des Occidentaux sur les Inuit au XVI ${ }^{\mathrm{e}}$ siècle. In AAVV, Destins croisés, cinq siècles de rencontres avec les Amérindiens (The first rencounters of Westeners and Inuit at XVI Century. In AAVV, Crossed destinies, five centuries of rencounters with native Americans) (pp. 393-410). Paris: Albin Michel / Unesco.

Bogliolo Bruna, G. (1994a). Singularitez, testimonianza etnografica, allegoria: L'immagine degli Eschimesi nell'iconografia del Rinascimento. In S. Ballo-Alagna (Ed.), Esplorazioni geografiche e immagine del mondo nei secoli XV e XVI, Atti del Convegno (Singularity, etnographic evidence, allegory: The image of Eskimos in the iconography of the Renaissance. In S. Ballo-Alagna (Ed.), Proceedings of the Conference on Geigraphic discoveries and world image at XV and XVI centuries) (pp.255-267). Messina: Grafo Editore.

Bogliolo Bruna, G. (1994b). Dalla tradizione testuale all’immagine grafica: L’inquietante tupinambá, la bella floridienne et la morigerata eschimese: L’alterità al femminile, ovvero lo "choc” esotico, sensuale e simbolico della scoperta nella letteratura odeporica del XVI secolo. In C.Claudio (Dir.), Genova, Colombo, il mare e l'emigrazione italiana nelle Americhe, Atti del XXVI Congresso Geografico Italiano (From the verbatim tradition to the graphical image: the worrying tupinamba, the beautiful floridian, the sober eskimo. The female alterity, i.e. the exotic, sensual and symbolic impact of the discovery in travel-literature of the XVI century. In C. Cerreti (Dir.), Genoa, Columbus, the sea and the Italian emigration to America, Proceedings of the XXVI Italian Geographic Congress) (pp. 767-777). Roma: Istituto della Enciclopedia Italiana Giovanni Treccani.

Bogliolo Bruna, G. (1999). Passer les frontières: Les Inuit du Labrador (fin du XVI ${ }^{\text {éme}}$-première moitié du XVIII ${ }^{\text {éme }}$ siècle. In R.-M.Loureiro, \& S. Gruzinski (Coords.), Passar as fronteiras, II Collóquio Internacional sobre Mediadores Culturais Séculos XV a XVIII (Crossing the borders: The Labrador Inuit (end XVI-first half of the XVIII century. In R.-M. Loureiro, \& S. Gruzinski (Dir.), Crossing the borders, II International Conference on Cultural Mediators, XV-XVIII centuries) (pp. 81-110). Lagos: Centro de Estudos Gil Eanes.

Bogliolo Bruna, G. (2000). Du mythe à la réalité : L’image des Esquimaux dans la littérature de voyage XVI-XVIII siècles (From the myth to the reality: Image of Eskimos in the travel-literature of XVI-XVIII centuries). In Proceedings of the 19th Congress of Historical Sciences, Commemorative volume. Oslo: Commission of History of International Relations.

Bogliolo Bruna, G. (2002). Explorer las cartes, les textes et les images: En quête de pygmées arctiques et d’homme-poissons. Prolégomènes à la première rencontre. In J. Malaurie (Dir.), De la vérité en ethnologie, Séminaire de Jean Malaurie 2000-2001 (Exploring the maps, the text and the images: Seeking for arctic pigmes and fish-men. Prolegomena to the firts rencounter. In J. Malaurie (Dir). About the trouth in ethnology. Seminars of Jean Malaurie 2000 - 2001) (pp. 79-96). Paris: Economica, 'Coll. Polaires'.

Bogliolo Bruna, G. (2002). Mestizaje de técnicas practicas y conocimientos en los inuit del Gran Norte de Canada y de Groenlandia (siglos XVI- XIX). In E. F. Paiva, \& C. M. Junho Anastasia (Orgs.), O trabalho mestiço. Maneiras de Pensar e Formas de Viver Séculos XVI a XIX 09-227 (North-Greenland Inuit's mestizo techniques, practices and knowledge (XVI-XIX centuries). In E. F. Paiva, \& C. M. Junho Anastasia (Orgs.), The mestizo work. Thinking and living at XVI-XIX centuries) (pp.209-228). São Paulo: Annablume editora.

Bogliolo Bruna, G. (2006). Planète métisse: Entretien avec Serge Gruzinski. In G. Bogliolo Bruna (Dir.), Thule, rivista di studi americanistici (Mestizo planet: Interview with Serge Gruzinski. In G. Bogliolo Bruna (Dir.), Thule, review of American studies) (pp. 247-253). Perugia: Centro studi Americanistici, “Circolo amerindiano”.

Bogliolo Bruna, G. (2006). Quand la pensée chamanique se matérialise en objet : Pérennité et métamorphoses de l’art inuit (Arctique canadien et Groenland de la préhistoire à la moitié du XX ${ }^{\text {éme }}$ siècle. In G. Bogliolo Bruna. (Dir.), Thule, rivista di studi americanistici (When the shamanic thinking materializes into objects: Perennity and matamorphosis in Inuit art (Canadian arctic \& Greenland, from the prehistory to the second half of XX century). In G. Bogliolo Bruna (Dir.), Thule, review of American studies) (pp. 247-253). Perugia: Centro Studi Americanistici, “Circolo amerindiano”.

Bogliolo Bruna, G. (2007). Apparences trompeuses: Sananguaq: Au cœur de la pensée Inuit (Treacherous appearances: Sananguaq: At the hearth of the Inuit thinking). Montigny-le-Bretonneux: Yvelinédition. 
Bogliolo Bruna, G. (2012). Jean Malaurie, une énergie créatrice (Jean Malaurie. A creative energy). Paris: Armand Colin.

Bogliolo Bruna, G. (2015). Les objets-messagers de l'art inuit (The messenger-objects of Inuit art). Paris: Harmattan / Institut Charles Cros, under press.

Brousseau, R. (2002). L’Art inuit au musée (Inuit art at the Museum). Québec: Musée d’Art Inuit Brousseau, Vieux-Québec.

Brousseau, R. (2003). Une culture millénaire. In Catalogue de l'exposition miniatures Inuit (A millenarian culture. In Catalog of the Inuit miniatures exhibition) (pp. 13-17). Montélimar: Musée de Montélimar.

Chevalier, J., \& Gheerbrant, A. (1996). Dictionnaire des symboles (Dictionary of symbols). Paris: Robert Laffont.

Desveaux, E. (2002). Kodiak, Alaska, les masques de la collection Alphonse Pinart du château-musée de Boulogne-sur-Mer (Kodiak, Alaska, masks of the Alphonse Pinart’s Boulogne-sur-Mer Castle-Museum). Paris: Musée du Quai Branly et Adam Biro.

Eggede, H. (1763). Description et histoire naturelle du Groenland (Description and natural history of Greenland). Copenhague \& Genève: Frères C. \& A. Philibert.

Feest, C. (1992). Native arts of North America. New York: Thames and Hudson.

Geffroy-Schneiter, B. (2006). Arts premiers Indiens, Eskimos, Aborigènes (Native art: Indians, Eskimos, Aborigines). Paris: Editions Assouline.

Gell, A. (1998). Art and agency: An anthropological theory. Oxford: Clarendon Press.

Gessain, R. (1947). Les Esquimaux du Groenland à l'Alaska (Eskimos from Greenland to Alaska). Paris: Ed. Bourrelier.

Gessain, R. (1950). Tupilek, à propos de figurines eskimo (Tupilek, about Eskimo small figures). Les Cahiers de Marottes et Violons d'Ingres, 8(juillet - août), 19-37.

Gessain, R. (1954). Figurine androgyne Eskimo (support de fusil sur le kayak) (Small androginous Eskimo figure (gun-stand on the kayak). Journal de la Société des Américanistes XLIII (Journal of Amaricanists’ Society XLIII), 207-217.

Gessain, R. (1959). L’art squelettique des Esquimo (Eskimo’s skeleton art). Journal de la Société des Américanistes, XLVIII (Journal of Amaricanists' Society XLVIII), 237-244.

Graburn, N., \& Stern, P. (1999). Ce qui est bien est beau. Un regard sur la beauté chez les Inuit du Canada (What is good is nice. Investigation on beauty at Canada Inuit). Terrain (Ground), 32(mars), 21-36.

Hessel, I., \& Hessel, D. (1998). Inuit art: An introduction (An introduction to Inuit art). London: British Museum.

Kaalund, B. (2001). L’art du Groenland. In J. Malaurie (Dir.), L'art du grand Nord (pp. 159-224) (Greenlad art. In J. Malaurie (Dir.), Far-North Art ). Paris: Citadelles \& Mazenod.

Kalm, P. (1977). Voyage de Pehr Kalm au Canada en 1749 (Travel of Pehr Kalm to Canada in 1749). Montréal: Pierre Tisseyre.

Lot-Falck, E. (1963). Régions Arctiques. In Collectif, L'art et les sociétés primitives à travers le monde (Arctic Regions. In Collective Book, Art and native societies in the world) (pp. 249-275). Paris: Hachette.

Malaurie, J. (1999). Hummocks I, Nord Groenland. Arctique Central Canadien (Hummocks I, North-Greenland. Canadian Central Arctic). Paris: Plon.

Malaurie, J. (2001). L'art du grand Nord (Far-North Art). Paris: Citadelles \& Mazenod.

Malaurie, J. (2002). De la vérité en ethnologie, Séminaire de Jean Malaurie 2000-2001 (About the trouth in ethnology. Seminars of Jean Malaurie 2000-2001). Paris: Economica, 'Coll. Polaires'.

Malaurie, J. (2003a). Hummoks 2: Alaska, avec les chasseurs de baleine, mer de Béring (Hummoks 2: Alaska, with wale hunters, Bering Sea). Paris: Pocket Plon 'Terre Humaine Poche'.

Malaurie, J. (2003b). L’Allée des Baleines (The Wales Avenue). Paris: Fayard Ed. Mille et Une Nuits.

Mandel, G. (2002). Les arts premiers Afrique noire, Australie, et Océanie, Amérique du Nord (Native art of Black Africa, Australia \& Oceania, North America). (E.Schelstraete, Trans.). Paris: É. Éditions Solar.

Martin, C.A., \& Clermont N. (1980). Les Inuit du Québec-Labrador méridional (The Inuit of Southern Québec-Labradorl). Etudes Inuit Studies, 4(1-2).

McGhee, R. \& Sutherlant, P. (2008). L'art du peuple du Dorset. In Upside down (Dorset people’s art. In Upside down) (pp. 42-75). Paris: Musée du Quai Branly.

McGhee, R. (1989). Le Canada au temps des envahisseurs (Canada at time of invaders). (B.Chabert, Trans.) Montréal: Éd. Libre Expression - Musée Canadien des Civilisations.

Morison, S. E. (1971). The European discovery of America: The northern voyages. Oxford: Oxford University Press.

Quppersimaan, G. (1992). Mon passé Eskimo (My Eskimo past). (C.Enel, Trans.). Paris: Gallimard “L'aube des peuples”.

Rasmussen, K. (1994). Du Groenland au Pacifique, deux ans d'intimité avec des tribus d'esquimaux inconnus (From Greenland to the Pacific. Two-year intimacy with unknown Eskimos) (C. Lund \& J. Bernard, Trans.) Paris: Éditions du Comité des travaux 
historiques et scientifiques.

Swinton, G. (1999). Sculpture of the Inuit (Inuit sculpture). Toronto: McClelland Stewart Inc.-The Canadian Publishers.

Thalbitzer, W. (1930). Les magiciens esquimaux, leurs conceptions du monde, de l'âme et de la vie (Eskimo magicians, their vision of the world, of the soul, of the life) J. Sté Améric, 22, 73-106.

Victor, P.-É. (1988). Eskimo. Paris: Stock.

Victor, P.-É., \& Robert-Lamblin, J. (1993). La civilisation du phoque. Légendes, rites et croyances des Eskimo d'Ammassalik (The seal civilization. Legends, rites and believes of Ammassalik Eskimos). Bayonne: Ed. Raymond Chabaud. 